\title{
Nitrogen fertilizer influence on wheat yield and use efficiency under different environmental conditions
}

\author{
Violeta Mandic $^{1 *}$, Vesna Krnjaja ${ }^{1}$, Zorica Tomic ${ }^{1}$, Zorica Bijelic ${ }^{1}$, Aleksandar Simic ${ }^{2}$, \\ Dragana Ruzic Muslic ${ }^{1}$, and Marija Gogic ${ }^{1}$
}

Managing $\mathrm{N}$ inputs in wheat production systems is an important issue in order to achieve maximum profitable production, and minimum negative environmental impact. The aim of this investigation carried out in dry land farming in the Vojvodina province (Serbia) was to estimate the effects of different $\mathrm{N}$ fertilization levels $\left(0,75\right.$, and $\left.150 \mathrm{~kg} \mathrm{~N} \mathrm{ha}^{-1}\right)$ on some quantitative traits, rain-use efficiency (RUE), $\mathrm{N}$ agronomic efficiency (NAE), and N use efficiency (NUE) in two Serbian winter wheat (Triticum aestivum L.) cultivars 'Pobeda' and 'Renesansa'. 'Pobeda' had higher grain yield (4437 kg ha-1) and RUE (8.32 $\mathrm{kg} \mathrm{ha}^{-1} \mathrm{~mm}^{-1}$ ) than 'Renesansa' (4265 kg ha-1 and $8 \mathrm{~kg} \mathrm{ha}^{-1} \mathrm{~mm}^{-1}$, respectively). Grain yield (4652 kg ha-1) and NUE (31.46 $\mathrm{kg} \mathrm{kg}^{-1} \mathrm{~N}$ ) were higher in the 2010-2011 season (favorable weather conditions) than in the 2011-2012 (4050 kg ha-1 and $27.59 \mathrm{~kg} \mathrm{~kg}^{-1} \mathrm{~N}$, respectively). The highly significant effect on grain yield (4396 and $\left.4494 \mathrm{~kg} \mathrm{ha}^{-1}\right), \mathrm{RUE}\left(8.24 \mathrm{and} 8.45 \mathrm{~kg}^{-}\right.$ $\mathrm{ha}^{-1} \mathrm{~mm}^{-1}$ ), NAE (3.11 and $2.21 \mathrm{~kg} \mathrm{~kg}^{-1} \mathrm{~N}$ ) and NUE (58.62 and $29.96 \mathrm{~kg} \mathrm{~kg}^{-1} \mathrm{~N}$ ) had levels of 75 and $150 \mathrm{~kg} \mathrm{~N} \mathrm{ha}^{-1}$. NAE and NUE declined at high $\mathrm{N}$ rates. Based on the results of this study, farmers should be advised that the use of large amounts of $\mathrm{N}$ increases production costs and reduce the economic benefits. The increase in wheat production is possible by selecting adapted genotypes with improved NUE.

Key words: Nitrogen use efficiency, quantitative traits, Triticum aestivum.

\section{INTRODUCTION}

Wheat (Triticum aestivum L.) is the most important cereal crop in world and is the staple food for humans. Average harvested area, total production and grain yield of wheat in the Serbia in 2012 was the 480539 ha, 1.9 million tons, and $4 \mathrm{tha}^{-1}$, respectively. In Serbia, the production is dominated by wheat 'Pobeda', 'Evropa 90', 'Renesansa', 'Dragana', 'Ljiljana' and 'Rusija' which occupy over 70\% of the total area under wheat (Dencic et al., 2010). The most common variety is 'Pobeda' with $25 \%$ of the total area under wheat. Nitrogen is the most limiting nutrient for wheat production that affects the rapid plant growth and improves grain yield. Many researches showed that $\mathrm{N}$ application increased grain yield (GY) of wheat (Subedi et al., 2007; Gorjanovic and Kraljevic-Balalic, 2008). Asif et al. (2012) concluded that number of fertile tiller per unit area, number of grain per spike (NGS), and harvest index were significantly increased by increasing $\mathrm{N}$ fertilization

${ }^{1}$ Institute for Animal Husbandry, Department of Animal Feed and Ecology, Autoput 16, 11080 Belgrade, Republic of Serbia. *Corresponding author (violeta_randjelovic@yahoo.com).

${ }^{2}$ University of Belgrade, Faculty of Agriculture, Department of Crop and Vegetable Science, Nemanjina 6, 11080 Belgrade, Republic of Serbia.

Received: 14 May 2014

Accepted: 25 November 2014.

doi:10.4067/S0718-58392015000100013 levels. Abedi et al. (2011) reported that higher GY (8230 $\mathrm{kg} \mathrm{ha}^{-1}$ ) was produced in treatment receiving $240 \mathrm{~kg} \mathrm{~N}$ $\mathrm{ha}^{-1}$ than in control $\left(3930 \mathrm{~kg} \mathrm{ha}^{-1}\right), 120 \mathrm{~kg} \mathrm{~N} \mathrm{ha}^{-1}$ (4400 $\left.\mathrm{kg} \mathrm{ha}^{-1}\right)$, and $360 \mathrm{~kg} \mathrm{~N} \mathrm{ha}^{-1}\left(6530 \mathrm{~kg} \mathrm{ha}^{-1}\right)$. Marino et al. (2009) concluded that increase the $\mathrm{N}$ rate increased hulled and unhulled GY, biomass accumulation, number of spike $\mathrm{m}^{-2}\left(\mathrm{NS} \mathrm{m}^{-2}\right)$, kernels $\mathrm{m}^{-2}$; decreased 1000 grain weight (TGW) and in some cases no differences were noticed among fertilized treatments for plant height $(\mathrm{PH})$ and number of spikelets per spike (NSS). Iqtidar et al. (2006) reported that increasing the $\mathrm{N}$ level from 50 to $200 \mathrm{~kg} \mathrm{ha}^{-1}$ significantly increased the $\mathrm{PH}$, total number of plants $\mathrm{m}^{-2}$, NGS, NS $\mathrm{m}^{-2}$, spike weight, and GY compared to $0 \mathrm{~kg} \mathrm{~N} \mathrm{Na}^{-1}$. Noureldin et al. (2013) reported that increasing $\mathrm{N}$ up to $180 \mathrm{~kg} \mathrm{ha}^{-1}$ increased GY and its components ( $\mathrm{NS} \mathrm{m}^{-2}$, spike length [SL], NGS, weight of grain per spike [WGS], and TGW). The efficiency of $\mathrm{N}$ application in winter wheat is an important indicator for rational fertilization of $\mathrm{N}$-fertilization. The values of $\mathrm{N}$ agronomic efficiency (NAE) in grain ranged from 10 to $30 \mathrm{~kg}$ grain kg ${ }^{-1}$ applied $\mathrm{N}$, and values over $30 \mathrm{~kg}$ grain $\mathrm{kg}^{-1}$ applied $\mathrm{N}$ are encountered in the well-organized systems of growing or at low levels of $\mathrm{N}$ fertilization on poor soils (Dobermann, 2005). Raun and Johnson (1999) have reported that globally, $\mathrm{N}$ use efficiency (NUE) in grain production is $33 \%$. Sieling et al. (1998) and $\mathrm{Li}$ et al. (2013) concluded that the NUE of wheat decreased with 
increasing $\mathrm{N}$ fertilization levels. Hatfield and Prueger (2004) and Bertic et al. (2007) have concluded that NUE by the crop depends on the weather conditions, especially rainfall and availability of $\mathrm{N}$ to the plants during growing season.

The present study was planned to find optimal $\mathrm{N}$ amount to enhance wheat grain yield with the hypothesis that the efficiency of applied $\mathrm{N}$ varies with different environment conditions. The goal of this paper was to investigate the effect of three level of $\mathrm{N}$ fertilization $\left(0,75\right.$, and $\left.150 \mathrm{~kg} \mathrm{~N} \mathrm{ha}^{-1}\right)$ on the quantitative traits and RUE, NAE, and NUE in Serbian winter wheat cultivars 'Pobeda' and 'Renesansa' in different environmental conditions. This research shows that the $\mathrm{N}$ amount affects expression of quantitative traits of wheat and utilization of genetic yield potential, as well as the efficiency of $\mathrm{N}$ utilization in years with different weather conditions.

\section{MATERIALS AND METHODS}

\section{Experimental details and treatments}

The experiments were carried out in dry land farming in the region of Southwest Vojvodina province (Serbia), at experimental field of Institute for Animal Husbandry of

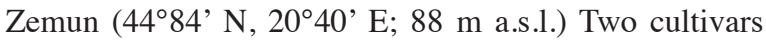
of winter wheat, 'Pobeda' (medium late) and 'Renesansa' (medium early), were grown during the seasons 20102011 and 2011-2012 at three $\mathrm{N}$ fertilization levels (0, 75 , and $150 \mathrm{~kg} \mathrm{~N} \mathrm{ha}^{-1}$ ). Preceding crop was maize (Zea mays L.) in both seasons. Wheat planting was done on in the optimal time (from 12-15 October). The sowing density was 500 seeds $\mathrm{m}^{-2}$. Plot size was $5 \mathrm{~m}^{2}$. A standard cultivation practice was applied. Nitrogen fertilizer KAN $(27 \% \mathrm{~N})$ was applied in March (early spring) at the tillering stage. Nitrogen fertilizer calcium ammonium nitrate KAN (produced in "HIP-Azotara", Pancevo, Serbia) was applied in March (early spring) at the tillering stage at a rate of 0,278 , and $556 \mathrm{~kg} \mathrm{ha}^{-1}$, respectively. Fertilizer KAN contains roughly $8 \% \mathrm{Ca}$ and $27 \% \mathrm{~N}(13.5 \%$ nitrate and $13.5 \%$ ammonium form).

\section{Agrochemical soil characteristics and climatic conditions during the experiment}

The soil type was a Chernozem (IUSS Working Group WRB, 2014) with $\mathrm{pH}$ in $\mathrm{H}_{2} \mathrm{O} 6.2$ (neutral reaction), 6.87\% organic matter, $4.33 \%$ humus, $0.33 \%$ total $\mathrm{N}, 17.97 \mathrm{mg}$ $\mathrm{NH}_{4}{ }^{+}-\mathrm{N} \mathrm{kg}^{-1}$, and $5.37 \mathrm{mg} \mathrm{NO}_{3}{ }^{-}-\mathrm{N} \mathrm{kg}^{-1}$. The $\mathrm{P}_{2} \mathrm{O}_{5}$ and $\mathrm{K}_{2} \mathrm{O}$ were 5.4 and $18.4 \mathrm{mg} 100 \mathrm{~g}^{-1}$ soil, respectively.

Climate diagram based on Walter and Lieth (1967) showed that in 2010-2011 season (total season rainfall $577.2 \mathrm{~mm}$ ) was not drought period; in 2011-2012 season (total season rainfall $490 \mathrm{~mm}$ ) period of drought were in November (beginning tillering stage), March (intensive process of tillering, rooting, and growth of foliage and beginning stem elongation stage), June and July (grain filling phase) (Figure 1).
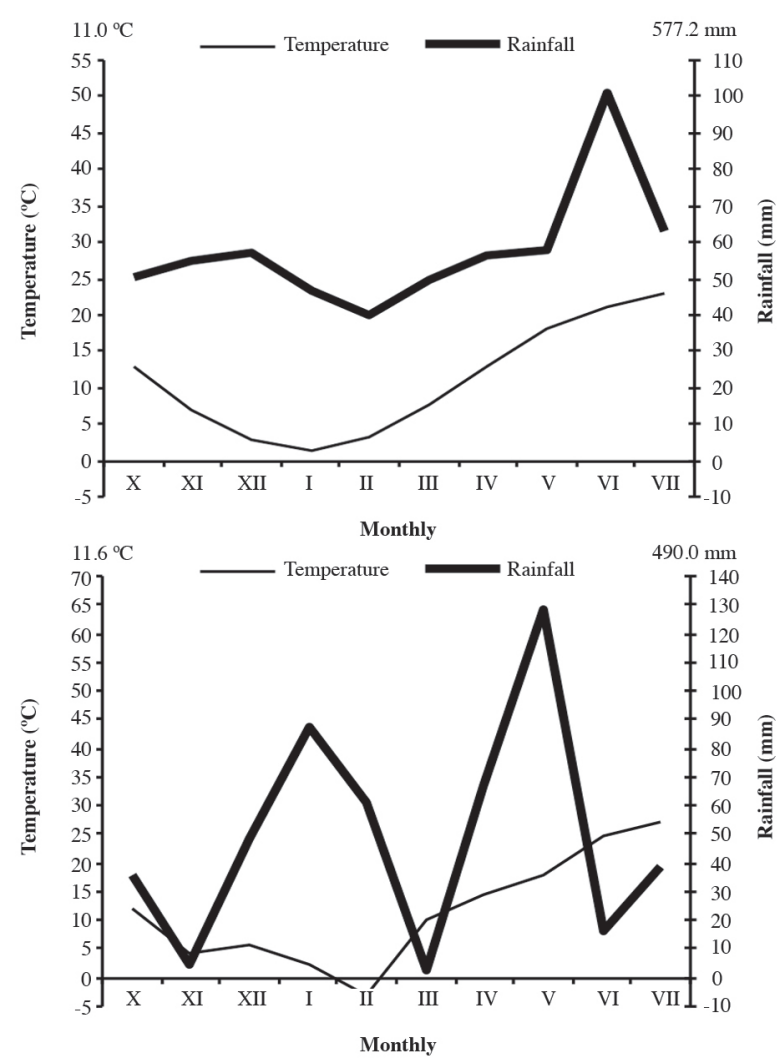

Figure 1. Climate diagram according to Walter in the 2010-2011 and 2011-2012 seasons for Zemun, Serbia.

\section{Data collection}

Grain yield (GY, kg ha-1) was harvested at the ripening stage and expressed at $14 \%$ moisture. The number of spikes $\mathrm{m}^{-2}\left(\mathrm{NS} \mathrm{m}^{-2}\right)$ was recorded before harvest. At harvest, plant height $(\mathrm{PH}, \mathrm{cm})$, spike length $(\mathrm{SL}, \mathrm{cm})$, number of spikelets per spike (NSS), number of grains per spike (NGS), weight of grains per spike (WGS, g), and 1000-grain weight (TGW, g) were measured from 30 random spikes from each sub plot. Rain-use efficiency (RUE) calculated according to Gwenzi et al. (2008) (grain yield/total seasonal rainfall, $\left.\mathrm{kg} \mathrm{ha}^{-1} \mathrm{~mm}^{-1}\right), \mathrm{N}$ agronomic efficiency (NAE) according to Delogu et al. (1998) ((GY at $\mathrm{N}$ treatment - GY at zero $\mathrm{N}$ )/applied $\mathrm{N}$ at $\mathrm{N}$ treatment, $\mathrm{kg}$ grain increase $\mathrm{kg}^{-1} \mathrm{~N}$ applied), and NUE according to Moll et al. (1982) (GY/N applied, $\mathrm{kg}_{\text {grain }} \mathrm{kg}^{-1} \mathrm{~N}$ applied).

\section{Statistical analysis}

Design of the experiments was randomized complete block design with four replicates. Data components were analyzed using ANOVA with STATISTICA (version 10; StatSoft, Tulsa, Oklahoma, USA). The significance level was set at $\mathrm{P} \leq 0.05$ and $\mathrm{P} \leq 0.01$. Differences between parameters means were assessed using Duncan's Multiple Range Test at $\mathrm{P} \leq 0.05$ level. Direct relationships between studied traits were analyzed with simple Pearson correlation coefficients. 


\section{RESULTS}

\section{Quantitative traits and grain yield}

ANOVA showed that cultivar had highly significant effect on NS $\mathrm{m}^{-2}$ and very significant on GY (Table 1). 'Pobeda' had significant higher NS $\mathrm{m}^{-2}$ (533.7) and GY (4437 $\mathrm{kg} \mathrm{ha}^{-1}$ ) than 'Renesansa' (500.9 and $4265 \mathrm{~kg} \mathrm{ha}^{-1}$, respectively). The season had highly significant effect on WGS, and very significant on PH, NSS, TGW, NS $\mathrm{m}^{-2}$, and GY. Values of these traits were significantly higher in the 2010-2011 season (favorable weather conditions) than in the 2011-2012. The $\mathrm{N}$ fertilization levels (75 and 150 $\mathrm{kg} \mathrm{N} \mathrm{ha}^{-1}$ ) have highly significant effect on NSS, WGS, $\mathrm{TGW}, \mathrm{NS} \mathrm{m}^{-2}$, and GY, and very significant on PH and SL. However, results showed that was not significant differences in values traits between these $\mathrm{N}$ levels, although the highest values of traits were recorded at 150 $\mathrm{kg} \mathrm{N} \mathrm{ha}^{-1}$. The interaction of season and $\mathrm{N}$ fertilization level had highly significant effect on PH. The interaction of cultivar and season had highly significant effect on $\mathrm{NS} \mathrm{m}{ }^{-2}$.

\section{Rain-use efficiency, $\mathbf{N}$ agronomic efficiency, and $\mathrm{N}$ use efficiency}

ANOVA showed that cultivar can differ on RUE (Table 2). 'Pobeda' had significant higher RUE $\left(8.32 \mathrm{~kg} \mathrm{ha}^{-1}\right.$ $\left.\mathrm{mm}^{-1}\right)$ than 'Renesansa' $\left(8 \mathrm{~kg} \mathrm{ha}^{-1} \mathrm{~mm}^{-1}\right)$. The NUE was significantly higher in $2010-2011$ season $(31.46 \mathrm{~kg}$ grain $\mathrm{kg}^{-1} \mathrm{~N}$ applied) than 2011-2012 (27.59 $\mathrm{kg}$ grain $\mathrm{kg}^{-1} \mathrm{~N}$ applied). The $\mathrm{N}$ fertilization level (75 and $150 \mathrm{~kg} \mathrm{ha}^{-1}$ ) had highly significant effect on RUE $(8.24$ and $8.45 \mathrm{~kg}$ $\mathrm{ha}^{-1} \mathrm{~mm}^{-1}$ ), NAE (3.11 and $2.21 \mathrm{~kg}$ grain increase $\mathrm{kg}^{-1}$ $\mathrm{N}$ applied) and NUE (58.62 and $29.96 \mathrm{~kg}_{\text {grain }} \mathrm{kg}^{-1} \mathrm{~N}$ applied) compared to control $\left(7.80 \mathrm{~kg} \mathrm{ha}^{-1} \mathrm{~mm}^{-1}, 0 \mathrm{~kg}\right.$

Table 1. Cultivar, season and nitrogen fertilization level effects on wheat quantitative traits.

\begin{tabular}{|c|c|c|c|c|c|c|c|c|c|}
\hline Factor & & $\mathrm{PH}$ & SL & NSS & NGS & WGS & TGW & $\mathrm{NS} \mathrm{m}^{-2}$ & GY \\
\hline $\begin{array}{l}\text { Cultivar } \\
\text { (A) }\end{array}$ & $\begin{array}{l}\text { Pobeda } \\
\text { Renesansa }\end{array}$ & $\begin{array}{l}77.4 \\
76.5\end{array}$ & $\begin{array}{l}7.36 \\
7.49\end{array}$ & $\begin{array}{l}16.02 \\
16.35\end{array}$ & $\begin{array}{l}27.9 \\
28.0\end{array}$ & $\begin{array}{l}0.99 \\
0.97\end{array}$ & $\begin{array}{l}35.07 \\
34.93\end{array}$ & $\begin{array}{l}533.7 \mathrm{a} \\
500.9 \mathrm{~b}\end{array}$ & $\begin{array}{l}4437 \mathrm{a} \\
4265 \mathrm{~b}\end{array}$ \\
\hline $\begin{array}{l}\text { Season } \\
\text { (B) }\end{array}$ & $\begin{array}{l}2010-2011 \\
2011-2012\end{array}$ & $\begin{array}{l}86.0 \mathrm{a} \\
67.9 \mathrm{~b}\end{array}$ & $\begin{array}{l}7.35 \\
7.50\end{array}$ & $\begin{array}{l}17.27 \mathrm{a} \\
15.09 \mathrm{~b}\end{array}$ & $\begin{array}{l}28.3 \\
27.7\end{array}$ & $\begin{array}{l}1.05 \mathrm{a} \\
0.90 \mathrm{~b}\end{array}$ & $\begin{array}{l}37.25 \mathrm{a} \\
32.75 \mathrm{~b}\end{array}$ & $\begin{array}{l}570.6 \mathrm{~s} \\
464.0 \mathrm{~b}\end{array}$ & $\begin{array}{l}4652 \mathrm{a} \\
4050 \mathrm{~b}\end{array}$ \\
\hline $\begin{array}{l}\text { N level, } \\
\mathrm{kg} \mathrm{ha}^{-1} \\
\text { (C) }\end{array}$ & $\begin{array}{l}0 \\
75 \\
150\end{array}$ & $\begin{array}{l}72.4 \mathrm{~b} \\
78.6 \mathrm{a} \\
79.9 \mathrm{a}\end{array}$ & $\begin{array}{l}6.94 b \\
7.59 a \\
7.75 a\end{array}$ & $\begin{array}{l}15.32 \mathrm{~b} \\
16.51 \mathrm{a} \\
16.71 \mathrm{a}\end{array}$ & $\begin{array}{l}25.9 \\
27.6 \\
30.5\end{array}$ & $\begin{array}{l}0.87 \mathrm{~b} \\
1.01 \mathrm{a} \\
1.05 \mathrm{a}\end{array}$ & $\begin{array}{l}33.91 \mathrm{~b} \\
35.17 \mathrm{a} \\
35.92 \mathrm{a}\end{array}$ & $\begin{array}{l}503.8 \mathrm{~b} \\
521.1 \mathrm{a} \\
527.0 \mathrm{a}\end{array}$ & $\begin{array}{l}4163 \mathrm{~b} \\
4396 \mathrm{a} \\
4494 \mathrm{a}\end{array}$ \\
\hline $\mathrm{F}$ test & $\begin{array}{l}\mathrm{A} \\
B \\
\mathrm{C} \\
\mathrm{A} \times \mathrm{B} \\
\mathrm{A} \times \mathrm{C} \\
\mathrm{B} \times \mathrm{C} \\
\mathrm{A} \times \mathrm{B} \times \mathrm{C}\end{array}$ & $\begin{array}{l}\text { ns } \\
*_{*}^{*} \\
*_{*}^{*} \\
\text { ns } \\
\text { ns }\end{array}$ & $\begin{array}{l}\text { ns } \\
\text { ns } \\
*_{*} \\
\text { ns } \\
\text { ns } \\
\text { ns } \\
\text { ns }\end{array}$ & \begin{tabular}{l|l} 
ns & \\
$* *$ \\
$*$ \\
$*$ \\
ns \\
ns \\
ns \\
ns
\end{tabular} & $\begin{array}{l}\text { ns } \\
\text { ns } \\
\text { ns } \\
\text { ns } \\
\text { ns } \\
\text { ns } \\
\text { ns }\end{array}$ & $\begin{aligned} & \mathrm{ns} \\
* & \\
* & \\
\mathrm{~ns} & \\
\mathrm{~ns} & \\
\mathrm{~ns} & \\
\mathrm{~ns} & \end{aligned}$ & $\begin{array}{c}\text { ns } \\
* * \\
* \\
\text { ns } \\
\text { ns } \\
\text { ns } \\
\text { ns }\end{array}$ & $\begin{array}{r}* * \\
* * \\
* \\
* \\
\text { ns } \\
\text { ns } \\
\text { ns }\end{array}$ & $\begin{array}{l}* * \\
* * \\
\text { ns } \\
\text { ns } \\
\text { ns } \\
\text { ns }\end{array}$ \\
\hline Mean & & 77.0 & 7.43 & 16.18 & 28.0 & 0.98 & 35.0 & 517.3 & 4351 \\
\hline
\end{tabular}

PH: plant height $(\mathrm{cm})$; SL: spike length $(\mathrm{cm})$; NSS: number of spikelets per spike; NGS: number of grain per spike; WGS: weight of grain per spike $(\mathrm{cm})$; TGW: 1000 grain weight $(\mathrm{g})$; $\mathrm{NS} \mathrm{m}^{-2}$ : number of spike $\mathrm{m}^{-2}$; GY: grain yield $\left(\mathrm{kg} \mathrm{ha}^{-1}\right)$.

Means followed by the same letter within a column are not significantly different according to Duncan's Multiple Range test ( $\mathrm{p} \leq 0.05)$.

${ }^{*},{ }^{* *}$ Significant at the 0.05 and 0.01 probability levels, respectively; ns: nonsignificant.
Table 2. Cultivar, season, and $\mathbf{N}$ fertilization level effects on rain-use efficiency (RUE), $\mathrm{N}$ agronomic efficiency (NAE), and $\mathrm{N}$ use efficiency (NUE).

\begin{tabular}{|c|c|c|c|c|}
\hline \multicolumn{2}{|l|}{ Factor } & \multirow{2}{*}{ 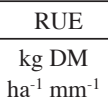 } & \multirow{2}{*}{$\begin{array}{c}\mathrm{NAE} \\
\mathrm{kg} \text { grain increase } \\
\mathrm{kg}^{-1} \mathrm{~N} \text { applied }\end{array}$} & \multirow{2}{*}{$\begin{array}{c}\mathrm{NUE} \\
\mathrm{kg} \text { grain } \mathrm{kg}^{-1} \\
\mathrm{~N} \text { applied }\end{array}$} \\
\hline & & & & \\
\hline Cultivar & Pobeda & $8.32 \mathrm{a}$ & 1.34 & 30.04 \\
\hline (A) & Renesansa & $8.00 \mathrm{~b}$ & 2.20 & 29.01 \\
\hline Season & $2010-2011$ & 8.06 & 1.26 & $31.46 \mathrm{a}$ \\
\hline (B) & 2011-2012 & 8.26 & 2.28 & $27.59 \mathrm{~b}$ \\
\hline N level, & 0 & $7.80 \mathrm{~b}$ & $0.0 \mathrm{~b}$ & $0.0 \mathrm{c}$ \\
\hline $\mathrm{kg} \mathrm{ha}^{-1}$ & 75 & $8.24 \mathrm{a}$ & $3.11 \mathrm{a}$ & $58.62 \mathrm{a}$ \\
\hline (C) & 150 & $8.45 \mathrm{a}$ & $2.21 \mathrm{a}$ & $29.96 b$ \\
\hline \multirow[t]{7}{*}{ F test } & Cultivar (A) & * & ns & ns \\
\hline & Season (B) & ns & ns & $* *$ \\
\hline & N level (C) & $* *$ & $* *$ & ** \\
\hline & $\mathrm{A} \times \mathrm{B}$ & ns & ns & ns \\
\hline & $\mathrm{A} \times \mathrm{C}$ & ns & ns & ns \\
\hline & $\mathrm{B} \times \mathrm{C}$ & ns & ns & $* *$ \\
\hline & $\mathrm{A} \times \mathrm{B} \times \mathrm{C}$ & ns & ns & ns \\
\hline Mean & & 8.16 & 1.77 & 29.53 \\
\hline
\end{tabular}

Means followed by the same letter within a column are not significantly different according to Duncan's Multiple Range test ( $\mathrm{p} \leq 0.05)$.

${ }^{*},{ }^{* *}$ Significant at the 0.05 and 0.01 probability levels, respectively; ns: nonsignificant.

grain increase $\mathrm{kg}^{-1} \mathrm{~N}$ applied, and $0 \mathrm{~kg}_{\text {grain }} \mathrm{kg}^{-1} \mathrm{~N}$ applied, respectively). These levels of $\mathrm{N}$ did not differ for RUE and NAE; NUE was significantly higher at $75 \mathrm{~kg} \mathrm{~N}$ $\mathrm{ha}^{-1}$ than $150 \mathrm{~kg} \mathrm{~N} \mathrm{ha}^{-1}$. The interaction of season and $\mathrm{N}$ fertilization level had highly significant effect on NUE.

\section{Correlation between studied properties}

Results show that the GY have very strong positive correlation with TGW (Table 3). PH was strong positively correlated with NSS, TGW, NS $\mathrm{m}^{-2}$ and GY, SL with NGS, NSS with WGS, NGS with WGS, and GY with NS $\mathrm{m}^{-2}$. Moderate positive correlations were found for $\mathrm{PH}$ with NGS and WGS, SL with NSS and WGS, NSS with NGS, TGW, NS $\mathrm{m}^{-2}$ and GY, WGS with TGW, GY and RUE, TGW with $\mathrm{NS} \mathrm{m}^{-2}$ and NAE, and NAE with NUE. Weak, low positive correlations were found for $\mathrm{PH}$ with SL (nonsignificant) and NUE, SL with RUE, NAE and NUE, NSS with RUE (nonsignificant) and NUE, WGS with NS $\mathrm{m}^{-2}$, TGW with RUE (nonsignificant) and NUE (nonsignificant), $\mathrm{NS} \mathrm{m}^{-2}$ with NUE (nonsignificant). Very weak to negligible correlations were found for $\mathrm{PH}$ with RUE and NAE, SL with TGW and NS $\mathrm{m}^{-2}$, NSS with NAE, NGS with TGW, NS $\mathrm{m}^{-2}$, NAE and NUE, WGS with NAE and NUE, NS $\mathrm{m}^{-2}$ with RUE and NAE, RUE with NAE and NUE.

\section{DISCUSSION}

Among wheat cultivars, significant differences were recorded for NS $\mathrm{m}^{-2}$ and GY; 'Pobeda' had significant higher NS $\mathrm{m}^{-2}$ and GY than 'Renesansa'. These traits are highly correlated, can be said that $\mathrm{NS} \mathrm{m}^{-2}$ is the important effective component in GY.

Plant height, NSS, WGS, TGW, NS $\mathrm{m}^{-2}$, and GY were affected by season. Values for these traits were significantly 
Table 3. Pearson correlation coefficient ( $r$ ) between quantitative traits of two wheat cultivars ('Pobeda' and 'Renesansa'), three $\mathrm{N}$ fertilization levels $\left(0,75\right.$, and $\left.150 \mathrm{~kg} \mathrm{~N} \mathrm{ha}^{-1}\right)$, and two growing seasons (2010-2011 and 2011-2012).

\begin{tabular}{|c|c|c|c|c|c|c|c|c|c|c|}
\hline Factor & $\mathrm{PH}$ & SL & NSS & NGS & WGS & TGW & $\mathrm{NS} \mathrm{m} \mathrm{m}^{-2}$ & GY & RUE & NAE \\
\hline SL & $0.35^{\mathrm{ns}}$ & 1.00 & & & & & & & & \\
\hline NSS & $0.80^{* *}$ & $0.62^{* * *}$ & 1.00 & & & & & & & \\
\hline NGS & $0.44^{* *}$ & $0.73^{* *}$ & $0.58^{* *}$ & 1.00 & & & & & & \\
\hline WGS & $0.69^{* *}$ & $0.67^{* * *}$ & $0.70^{* *}$ & $0.86^{* *}$ & 1.00 & & & & & \\
\hline TGW & $0.71^{* *}$ & $0.12^{\text {ns }}$ & $0.51^{* *}$ & $0.19^{\mathrm{ns}}$ & $0.50^{* *}$ & 1.00 & & & & \\
\hline $\mathrm{NS} \mathrm{m}^{-2}$ & $0.82^{* *}$ & $0.02^{\mathrm{ns}}$ & $0.57^{* *}$ & $0.12^{\text {ns }}$ & $0.37^{*}$ & $0.67^{* * *}$ & 1.00 & & & \\
\hline GY & $0.74^{* *}$ & $0.12^{\mathrm{ns}}$ & $0.53^{* *}$ & $0.19^{\mathrm{ns}}$ & $0.51^{* * *}$ & $0.99^{* *}$ & $0.70^{* * *}$ & 1.00 & & \\
\hline RUE & $0.11^{\mathrm{ns}}$ & $0.31^{*}$ & $0.25^{\mathrm{ns}}$ & $0.29^{*}$ & $0.62^{* *}$ & $0.24^{\mathrm{ns}}$ & $0.08^{\text {ns }}$ & $0.30^{*}$ & 1.00 & \\
\hline NAE & $0.01^{\mathrm{ns}}$ & $0.40^{* *}$ & $0.12^{\mathrm{ns}}$ & $0.15^{\mathrm{ns}}$ & $0.19^{\mathrm{ns}}$ & $0.42^{* *}$ & $0.16^{\mathrm{ns}}$ & $0.38^{* * *}$ & $0.18^{\mathrm{ns}}$ & 1.00 \\
\hline NUE & $0.32^{*}$ & $0.38^{* * *}$ & $0.33^{*}$ & $0.13^{\mathrm{ns}}$ & $0.16^{\mathrm{ns}}$ & $0.27^{\mathrm{ns}}$ & $0.20^{\mathrm{ns}}$ & $0.33^{*}$ & $0.04^{\mathrm{ns}}$ & $0.53^{* *}$ \\
\hline
\end{tabular}

* ${ }^{* *}$ Significant at the 0.05 and 0.01 probability levels, respectively; ${ }^{\text {ns: }}$ nonsignificant.

PH: plant height; SL: spike length; NSS: number of spikelets per spike; NGS: number of grain per spike; WGS: weight of grain per spike; TGW: 1000 grain weight; NS $\mathrm{m}^{-2}$ : number of spike $\mathrm{m}^{-2}$; GY: grain yield; RUE: rain-use efficiency; NAE: $\mathrm{N}$ agronomic efficiency and $\mathrm{N}$ use efficiency (NUE).

higher in favorable environmental conditions in 20102011 season. Drought stress during stem elongation stage (late March to early April in 2012) reduced the PH and NSS. Plants responded by reducing $\mathrm{PH}$ because stem growth was slow. Also, other researchers showed that drought stress during stem elongation stage reduced the PH (Shamsi and Kobraee, 2011; Gevrek and Atasoy, 2012) and NSS (Sener et al., 2000; Gevrek and Atasoy, 2012). In June and July 2012, water stress during grain filling stage shortened grain filling period and reduced WGS and TGW. Garcia del Moral et al. (2003) and Ilker et al. (2011) pointed that drought after flowering of wheat adversely affects DM translocation in the grain. Bauder (2001) reported that drought stress during maturity stage decreases yield about $10 \%$. NS $\mathrm{m}^{-2}$ is a trait dependant on the intensity of tillering. The intensity of tillering is a varietal characteristic which is caused by environmental factors. Wheat sown in 2010 had a good set of plants as a result of favorable weather conditions during germination and tillering. On the other hand, the drought in the phase of germination 2011 (beginning November) and early tillering (second half of November) resulted in a sparse set of plants, and lower intensity of tillering, which resulted in lower $\mathrm{NS} \mathrm{m}^{-2}$. Grain yield was significant higher in 2010-2011. In June 2012, the wheat was exposed to high temperatures and lack of water leading to a shortening of grain filling process and accelerated ripening, reduction of WGS and TGW and hence yield. In addition, the $\mathrm{NS} \mathrm{m}^{-2}$ was higher in the 2010-2011 season, and this feature had a highly significant correlation with the GY. In both seasons there was no shortening of SL, because there was enough water at the time of head (inflorescence) emergence and flowering. The drought stress at flowering stage reduces the SL. Gevrek and Atasoy (2012) reported that SL was not significantly affected by drought stress after postanthesis stage. The NGS did not differ in seasons because there were unfavorable climatic conditions (heat stress, drought) during flowering and pollination (end of May).

Plant height, SL, NSS, WGS, TGW, NS $\mathrm{m}^{-2}$, and GY were significantly increased with increasing $\mathrm{N}$ level. However, there was no significant difference between 75 and $150 \mathrm{~kg} \mathrm{~N} \mathrm{ha}^{-1}$. Also, many authors reported that increasing N level increased PH (Ali et al., 2000; Sobh et al., 2000; Jan et al., 2002; Iqtidar et al., 2006; Ali et al., 2011), SL (Ali et al., 2000; Asif et al., 2009; El-Gizawy, 2009; Ali et al., 2011; Iqbal et al., 2012; Gheith et al., 2013), NSS (Modhej et al., 2008; Ali et al., 2011; Iqbal et al., 2012), WGS (Noureldin et al., 2013), TGW (Ali et al., 2000; Iqtidar et al., 2006; Ali et al., 2011; Abedi et al., 2011) and NS m${ }^{-2}$ (Ahmed Seham et al., 2009; Ansar et al., 2010; Njuguna et al., 2010; Abedi et al., 2011; Iqbal et al., 2012). Many studies have shown that the best yields achieved with 70 to $120 \mathrm{~kg} \mathrm{~N} \mathrm{ha}^{-1}$ (Teixeira Filho et al., 2007; 2010; Njuguna et al., 2010; Espindula et al., 2010; Abedi et al., 2011; Iqbal et al., 2012; Noureldin et al., 2013). High yields achieved in the control can be attributed to the high content of organic matter and humus in the soil in which they conducted experiments, since in the process of mineralization, which is more intensive in terms of sufficient amounts of rainfall and higher air temperatures in March and April, a significant amount of available $\mathrm{N}$ for plants is released (Cabrera et al., 2005). NGS was higher in both $\mathrm{N}$ fertilization levels compared to control, however differences were not significant. Gevrek and Atasoy (2012) found that N application had no significant effect on NGS. On the other hand, Iqtidar et al. (2006) and Abedi et al. (2011) reported that NGS significantly increased with increasing $\mathrm{N}$ fertilization levels.

Water resources in the Republic of Serbia are limited and about $1 \%$ of arable land is irrigated (Mandic et al., 2013). Wheat is not irrigated so the key to a stable production is rain-use efficiency (RUE). Genotypes with improved RUE are particularly beneficial under low rainfall conditions. 'Pobeda' had a better use of rainfall than 'Renesansa' since its RUE value was significantly higher. The NUE depends of the water availability. In our experimental fields, water was a limiting factor during the cropping season 2011-2012 with $490 \mathrm{~mm}$ and NUE had lower value. RUE, NAE, and NUE significantly increased with increase $\mathrm{N}$ fertilization level than in control. NAE and NUE were reduced in highest $\mathrm{N}$ level, especially NUE. This can be attributed to $\mathrm{N}$ loss in ecosystem. Russell (1967) found that average NAE of $7.2 \mathrm{~kg}$ grain increase 
$\mathrm{kg}^{-1} \mathrm{~N}$ applied at $25 \mathrm{~kg} \mathrm{~N}^{-1}$ and $5.1 \mathrm{~kg}$ grain increase $\mathrm{kg}^{-1} \mathrm{~N}$ applied at $50 \mathrm{~kg} \mathrm{~N} \mathrm{ha}^{-1}$. Serret et al. (2008) reported that NAE significantly reduced in the highest $\mathrm{N}$ fertilizer level. Hooper (2010) reported that average NAE for wheat about $20-25 \mathrm{~kg}$ grain increase $\mathrm{kg}^{-1} \mathrm{~N}$ applied worldwide, $33 \mathrm{~kg}$ grain increase $\mathrm{kg}^{-1} \mathrm{~N}$ applied in Australia and about 15-20 kg grain increase $\mathrm{kg}^{-1} \mathrm{~N}$ applied in South Australia. Also, reported that $\mathrm{N}$ fertilization increased NUE, but the highest N level reduced NUE. Somarin et al. (2010) and Noureldin et al. (2013) reported that increased $\mathrm{N}$ level reduced NUE.

Correlation coefficients between GY and PH, TGW and $\mathrm{NS} \mathrm{m}^{-2}$ were significant and high. Also, GY had a significantly moderate positive correlation with NSS, WGS, RUE, NUE, and NAE. These traits were important for selection and breeding criteria to GY improving. Many authors reported that in wheat grown in the different environments GY was significantly correlated with NSS and TGW (Lad et al., 2003; Kashif and Khaliq, 2004; Aycecik and Yildirim, 2006; Akram et al., 2008; Joshi et al., 2008; Wu et al., 2012). Contrary to our research, Shahid et al. (2002), Akram et al. (2008), and Joshi et al. (2008) reported that GY was negatively correlated with $\mathrm{PH}$. In regard to traits for which no significant correlation was determined (PH with RUE and NAE, SL with TGW, NS $\mathrm{m}^{-2}$ and GY, NSS with RUE and NAE, NGS with TGW, NS m ${ }^{-2}$, GY, NAE and NUE, WGS with NAE and NUE, TGW with NUE, NS m ${ }^{-2}$ with RUE, NAE and NUE, and RUE with NAE and NUE), it is possible to conduct simultaneous selection/breeding for both traits. This relates particularly to correlation between RUE and NUE.

\section{CONCLUSIONS}

'Pobeda' had higher grain yield (GY) than 'Renesansa', because it had higher $\mathrm{NSm}^{-2}$ and better used the rainfall during growing seasons. Drought in certain stages of development of plants in 2011-2012 led to a reduction in yield components (number of spikelets per spike, weight of grain per spike, 1000 grain weight, number of spikes per square meter) and GY. Also, $\mathrm{N}$ use efficiency (NUE) was lower in this season. Results showed that plant height, yield component, GY, rain-use efficiency, N agronomic efficiency, and NUE significantly increased with increasing $\mathrm{N}$ fertilization levels. However, application of 75 or $150 \mathrm{~kg} \mathrm{~N} \mathrm{ha}^{-1}$ did not differ significantly, except for NUE that significantly decreases at higher $\mathrm{N}$ level. Therefore, the application of $75 \mathrm{~kg} \mathrm{~N}^{-1}$ gives the minimum loss of $\mathrm{N}$ in the ecosystem as well as the lowest cost of production of wheat in Serbia.

\section{ACKNOWLEDGEMENTS}

This research was conducted within the project TR 31053 funded by Ministry of Education, Science and Technological Development of Republic of Serbia.

\section{LITERATURE CITED}

Abedi, T., A. Alemzadeh, and S.A. Kazemeini. 2011. Wheat yield and grain protein response to nitrogen amount and timing. Australian Journal of Crop Science 5:330-336.

Ahmed Seham, M.M., A.A. Abdul Galil, H.A. Basha, and A.A.E. Mowafy. 2009. Response of wheat to fertilization under sandy soil conditions. Zagazig Journal of Agricultural Research 36:1045-1067

Akram, Z., S. Ajmal, and M. Munir. 2008. Estimation of correlation coefficient among some yield parameters of wheat under rainfed conditions. Pakistan Journal of Botany 40:1777-1781.

Ali, A., A. Ahmad, W.H. Syed, T. Khaliq, M. Asif, M. Aziz, et al. 2011. Effects of nitrogen on growth and yield components of wheat (report). Science International (Lahore) 24:331-332.

Ali, A., M.A. Choudhry, M.A. Malik, R. Ahmad, and Saifullah. 2000. Effect of various doses of nitrogen on the growth and yield of two wheat cultivar. Pakistan Journal of Botany 3:1004-1005.

Ansar, M., N.M. Cheema, and M.H. Leitch. 2010. Effect of agronomic practices on the development of septoria leaf blotch and ITS subsequent effect on growth and yield components of wheat. Pakistan Journal of Botany 43:2125-2138.

Asif, M., A. Ali, M.E. Safdar, M. Maqsood, S. Hussain, and M. Arif. 2009. Growth and yield of wheat as influenced by different levels of irrigation and nitrogen. International Journal of Agriculture and Applied Sciences 1:25-28

Asif, M., M. Maqsood, A. Ali, S.W. Hassan, A. Hussain, S. Ahmad, et al. 2012. Growth yield components and harvest index of wheat (Triticum aestivum L.) affected by different irrigation regimes and nitrogen management strategy. Science International (Lahore) 24:215-218.

Aycecik, M., and T. Yildirim. 2006. Path coefficient analysis of yield and yield components in bread wheat (Triticum aestivum $\mathrm{L}$.) genotypes. Pakistan Journal of Botany 38:417-424.

Bauder, J. 2001. Irrigating with limited water supplies. Montana State University Communications Services, Bozeman, Montana, USA.

Bertic, B., Z. Loncaric, V. Vukadinovic, Z. Vukobratovic, and V. Vukadinovic. 2007. Winter wheat yield responses to mineral fertilization. Cereal Research Communications 35:245-248.

Cabrera, M.L., D.E. Kissel, and M.F. Vigil. 2005. Nitrogen mineralization from organic residues: Research opportunities. Journal of Environmental Quality 34:75-79.

Delogu, G., L. Cattivelli, N. Pecchioni, D. De Falcis, T. Maggiore, and A.M. Stanca. 1998. Uptake and agronomic efficiency of nitrogen in winter barley and winter wheat. European Journal of Agronomy 9:11-20.

Dencic, S., B. Kobiljski, G. Mladenovic, and N. Kovacevic. 2010. Sadašnjost i budućnost NS sortimenta pšenice. 45. Savetovanje agronoma Srbije, 30.01-05.02.2011, Zlatibor. Zbornik referata, Institut za ratarstvo i povrtarstvo, Novi Sad, 15-25.

Dobermann, A. 2005. Nitrogen use efficiency: State of the art. p. 1-16. IFA International Workshop on Enhanced-Efficiency Fertilizers, Frankfurt. 28-30 June. International Fertilizer Industry Association (FIA), Paris, France.

El-Gizawy, N.K.B. 2009. Effect of planting dates and fertilizer application on yield of wheat under no tillage system. World Journal of Agricultural Sciences 5:777-783.

Espindula, M.C., V.S. Rocha, M.A. Souza, J.A.S Grossi, e L.T. Souza. 2010. Doses e formas de aplicação de nitrogênio no desenvolvimento e produção da cultura do trigo. Ciência e Agrotecnologia 34:1404-1411.

Garcia del Moral, L.F., Y. Rharrabti, D. Villegas, and C. Royo. 2003. Evaluation of grain yield and its components in durum wheat under Mediterranean conditions: an ontogenic approach. Agronomy Journal 95:266-274

Gevrek, M.N., and G.D. Atasoy. 2012. Effect of post anthesis drought on certain agronomical characteristics of wheat under to different nitrogen application conditions. Turkish Journal of Field Crops 17:19-23. 
Gheith, E.M.S., O.Z. El-Badry, and S.A. Wahid. 2013. Sowing dates and nitrogen fertilizer levels effect on grain yield and its components of different wheat genotypes. Research Journal of Agriculture and Biological Sciences 9:176-181.

Gorjanovic, B., and M. Kraljevic-Balalic. 2008. Sadrzaj proteina u zrnu genotipova hlebne psenice na tri nivoa ishrane azotom. Selekcija i semenarstvo 14:59-62.

Gwenzi, W., M. Taru, Z. Mutema, J. Gotosa, and S.M. Mushiri. 2008. Tillage system and genotype effects on rainfed maize (Zea mays L.) productivity in semi-arid Zimbabwe. African Journal of Agricultural Research 3:101-110.

Hatfield, J.L., and J.H. Prueger. 2004. Nitrogen over-use, under-use, and efficiency. Proceedings of the $4^{\text {th }}$ International Crop Science Congress, Brisbane, Australia. 26 September-1 October 2004. The Regional Institute Ltd., Gosford, New South Wales, Australia.

Hooper, P. 2010. Strategic applications of nitrogen fertiliser to increase the yield and nitrogen use efficiency of wheat. Thesis MSc. University of Adelaide, School of Agriculture, Food and Wine, Adelaide, South Australia, Australia.

Ilker, E., Ö. Tatar, F. Aykut Tonk, and M. Tosun. 2011. Determination of tolerance level of some wheat genotypes to post-anthesis drought. Turkish Journal of Field Crops 16:59-63.

Iqbal, J., K. Hayat, and S. Hussain. 2012. Effect of sowing dates and nitrogen levels on yield and yield components of wheat (Triticum aestivum L.) Pakistan Journal of Nutrition 11:531-536.

Iqtidar, H., K.M. Ayyaz, and K.E. Ahmad. 2006. Bread wheat varieties as influenced by different nitrogen levels. Journal of Zhejiang University-SCIENCE B 7:70-78.

IUSS Working Group WRB. 2014. World reference base for soil resources 2014. International soil classification system for naming soils and creating legends for soil maps. World Soil Resources Reports nr 106. FAO, Rome, Italy.

Jan, M.T., M. Shah, and S. Khan. 2002. Type of N fertilizer rate and timing effect on wheat production. Sarhad Journal of Agriculture $18: 405-410$

Joshi, B.K., A. Mudwari, and D.B. Thapa. 2008. Correlation and path coefficients among quantitative traits in wheat (Triticum aestivum L.) Nepal Journal of Science and Technology 9:1-5.

Kashif, M., and I. Khaliq. 2004. Heritability, correlation and path coefficient analysis for some metric traits in wheat. International Journal of Agriculture and Biology 6:138-142.

Lad, D.B., N.D. Bangar, T.J. Bhor, G.D. Mukherkar, and A.B. Biradar. 2003. Correlation and path coefficient analysis in wheat. Journal of Maharashtra Agricultural Universities 28:23-25.

Li, L., J.P. Hong, H.T. Wang, Y.H. Xiu, and L. Zhang. 2013. Effects of watering and nitrogen fertilization on the growth, grain yield, and water- and nitrogen use efficiency of winter wheat. Chinese Journal of Applied Ecology 24:1367-1373.

Mandic, V., A. Simic, Z. Tomic, V. Krnjaja, Z. Bijelic, G. Marinkov, et al. 2013. Effect of drought and foliar fertilization on maize production. p. 416-429. Proceedings of the $10^{\text {th }}$ International Symposium Modern Trends in Livestock Production, Belgrade, Serbia. 2-4 October. Institute for Animal Husbandry, ZemunBelgrade, Serbia.

Marino, S., R. Tognetti, and A. Alvino. 2009. Crop yield and grain quality of emmer populations grown in central Italy, as affected by nitrogen fertilization. European Journal of Agronomy 31:233-240.

Modhej, A., A. Naderi, Y. Emam, A. Aynehband, and Gh. Normohamadi. 2008. Effects of post-anthesis heat stress and nitrogen levels on grain yield in wheat (T. durum and T. aestivum) genotypes. International Journal of Plant Production 2:257-268.
Moll, R.H., E.J. Kamprath, and W.A. Jackson. 1982. Analysis and interpretation of factors which contribute to efficiency of nitrogen utilization. Agronomy Journal 74:562-564.

Njuguna, M.N., M. Munene, H.J. Muangi, J.K. Waweru, and T.E. Akuja. 2010. Effect of seeding retained nitrogen fertilizer on wheat grain yield. Journal of Animal and Plant Sciences 7:843840 .

Noureldin, N.A., H.S. Saudy, F. Ashmawy, and H.M. Saed. 2013. Grain yield response index of bread wheat cultivars as influenced by nitrogen levels. Annals of Agricultural Science 58:147-152.

Raun, W.R., and G.V. Johnson. 1999. Improving nitrogen use efficiency for cereal production. Agronomy Journal 91:357.

Russell, J.S. 1967. Nitrogen fertilizer and wheat in a semi-arid environment. 2. Climatic factors affecting response. Australian Journal of Experimental Agriculture and Animal Husbandry 8:223-231

Sener, O., M. Kılınç, and T. Yağbasanlar. 2000. Estimation of inheritance of some agronomical characters in common wheat by diallel cross analysis. Turkish Journal of Agriculture and Forestry 24:121-127.

Serret, M.D., I. Ortiz-Monasterio, A. Pardo, and J.L. Araus. 2008. The effect of urea fertilization and genotype on yield, NUE, d15N and d13C in wheat. Annals of Applied Biology 153:243-257.

Shahid, M., M. Fida, and M. Tahir. 2002. Path coefficient analysis in wheat. Sarhad Journal of Agriculture 18:383-388.

Shamsi, K., and S. Kobraee. 2011. Bread wheat production under drought stress conditions. Annals of Biological Research 2:352-358.

Sieling, K., H. Schroder, M. Finck, and H. Hanus. 1998. Yield, $\mathrm{N}$ uptake, and apparent $\mathrm{N}$-use efficiency of winter wheat and winter barley grown in different cropping systems. Journal of Agricultural Science131:375-387.

Sobh, M.M., M.S. Sharshar, and S.A. El-Said. 2000. Response of wheat to nitrogen and potassium application in a salt affected soil. Journal Product Development 5:83-98.

Somarin, S.J., R.Z. Mahmoodabad, A. Yari, M. Khayatnezhad, and R. Gholamin. 2010. Study of agronomical nitrogen use efficiency of durum wheat affected by nitrogen fertilizer and plant density. World Applied Sciences Journal 11:674-681.

Subedi, K.D., B.L. Ma, and A.G. Xue. 2007. Planting date and nitrogen effects on grain yield and protein content of spring wheat. Crop Science 47:36-44.

Teixeira Filho, M.C.M., S. Buzetti, R.C.F. Alvarez, J.G. Freitas, O. Arf, e M.E. Sá. 2007. Resposta de cultivares de trigo irrigado por aspersão ao nitrogênio em cobertura na região do Cerrado. Acta Scientiarum Agronomy 29:421-425.

Teixeira Filho, M.C.M., S. Buzetti, M. Andreotti, O. Arf, e C.G.S. Benett. 2010. Doses, fontes e épocas de aplicação de nitrogênio em trigo irrigado em plantio direto. Pesquisa Agropecuária Brasileira 45:797-804.

Walter, H., and H. Lieth. 1967. Klimadiagram-Weltatlas. VEB Gustav Fischer Verlag, Jena, Germany.

Wu, X., X. Chang, and R. Jing. 2012. Genetic insight into yieldassociated traits of wheat grown in multiple rain-fed environments. PLoS One 7:31249. 